\title{
उMR
}

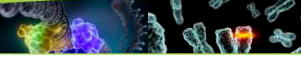

\section{Amino acid composition of royal jelly harvested at different times after larval transfer}

\author{
H. Jie, P.M. Li, G.J. Zhao, X.L. Feng, D.J. Zeng, C.L. Zhang, M.Y. Lei, \\ M. Yu and Q. Chen \\ Laboratory of Medicinal Animal, \\ Chongqing Institute of Medicinal Plant Cultivation, Chongqing, China \\ Corresponding author: Q. Chen \\ E-mail: apidae@126.com
}

Genet. Mol. Res. 15 (3): gmr.15038306

Received March 9, 2016

Accepted April 8, 2016

Published August 12, 2016

DOI http://dx.doi.org/10.4238/gmr.15038306

Copyright $(\subset 2016$ The Authors. This is an open-access article distributed under the terms of the Creative Commons Attribution ShareAlike (CC BY-SA) 4.0 License.

\begin{abstract}
The amino acids in royal jelly (RJ) have a wide range of pharmacological and health-promoting functions in humans. Multiple studies on the amino acid quality and composition in RJ have investigated $\mathrm{RJ}$ harvested at $72 \mathrm{~h}$ after larval transfer. In contrast, the concentration of amino acids in RJ harvested before $72 \mathrm{~h}$ remains unknown. In this study, the concentration of free amino acids (FAAs) and total amino acids (TAAs) in RJ harvested at 13 time points between 24 and $72 \mathrm{~h}$ after transfer of ten Apis mellifera colonies were measured. Our results indicated that the most abundant FAAs were Pro, Phe, Lys, Glu, and Tyr, whereas the most abundant TAAs were Asp, Glu, Leu, Lys, and Val. The total FAA concentration in RJ increased with increasing harvest time, from $4.30 \mathrm{mg} / \mathrm{g}$ at $24 \mathrm{~h}$ to $9.48 \mathrm{mg} / \mathrm{g}$ at $72 \mathrm{~h}$. In contrast, the variation in concentration of TAAs observed was a decrease-increase-decrease trend with $40 \mathrm{~h}(149.53 \mathrm{mg} / \mathrm{g})$ and $52 \mathrm{~h}(169.62 \mathrm{mg} / \mathrm{g})$ as inflection
\end{abstract}

Genetics and Molecular Research 15 (3): gmr.15038306 
points. The highest and lowest concentrations of TAA were 197.96 and $121.32 \mathrm{mg} / \mathrm{g}$ at 24 and $72 \mathrm{~h}$, respectively. To our knowledge, this is the first study to investigate the concentration changes of FAAs and TAAs prior to $72 \mathrm{~h}$ after transfer. Our results will provide theoretical support to guide production practices of beekeeping, as well as elucidate the relationship between the harvest time point and RJ content.

Key words: Apis mellifera; Royal jelly; Amino acid; Concentration; Harvest time

\section{INTRODUCTION}

Royal jelly (RJ) is a yellowish-white cream secreted by the hypopharyngeal and mandibular glands of worker honey bees from 5-15 days of age. RJ is widely recognized as a healthy and functional food for humans (Knecht and Kaatz, 1990). At the same time, RJ is the only diet for the queen throughout her life and for honey bee larvae within three days of age (Townsend and Lucas, 1940; Scarselli et al., 2005). The consumption of RJ affects DNA methylation processes in the queen and promotes the development of gynes (Kucharski et al., 2008). It has been reported that RJ possesses a wide variety of pharmacological activities, including antibacterial, anticancer, antihypertensive, and antioxidative effects, which could serve therapeutic purposes promoting human health (Townsend et al., 1959; Tamura et al., 1987; Bíliková et al., 2001; Tokunaga et al., 2004; Guo et al., 2009; Kim et al., 2010; Karaca et al., 2012; Mihajlovic et al., 2014). Hence, RJ is now widely used in therapeutic products, health foods, and cosmetics (Han et al., 2012).

$\mathrm{RJ}$ is a complex compound, which contains $60-70 \%$ moisture, $12-15 \%$ crude proteins, $10-16 \%$ carbohydrates, $3-7 \%$ lipids, as well as traces of mineral salts, vitamins, and free amino acids (Nation and Robinson, 1971; Lercker et al., 1981; Howe et al., 1985; Crane, 1990; Chen and Chen, 1995). The RJ proteins have a wide range of pharmacological and health-promoting functions in humans. As a highly protein-rich food, the nutrition of RJ is to a large extent determined by the amino acid concentrations (Matloubi et al., 2004). Thus, determination of the concentrations of total amino acids (TAAs) and free amino acids (FAAs) is an effective method for evaluating RJ quality (Boselli et al., 2003; Wu et al., 2009; Zhao, 2014).

In general, commercial $\mathrm{RJ}$ is produced by transferring one-day-old larvae into artificial queen cells to induce nurse bees to secrete RJ in the cells (Chen et al., 2002). The majority of the produced RJ is harvested at three days $(72 \mathrm{~h}$ ) after larval transfer because, at this time, the amount of RJ in the queen cells reaches its peak (Lercker et al., 1981). In recent years, some producers sell RJ that was harvested at two days $(48 \mathrm{~h})$ or one day $(24 \mathrm{~h})$ after transfer. These earlier harvests shorten the production cycle, but few studies have investigated any difference in the nutritional composition of RJ harvested at different times after transfer. Shen (1991) compared the composition of RJ harvested at 48 and $72 \mathrm{~h}$ after transfer, with the aim of identifying freshness indicators. In addition, Zheng et al. (2011) investigated the changes in moisture, protein, 10-HDA, total sugar, acidity value, and superoxide dismutase activity in RJ harvested at 24, 48, and $72 \mathrm{~h}$ after transfer. However, to the best of our knowledge, no study has investigated the changes in amino acids in RJ harvested prior to $72 \mathrm{~h}$ after transfer.

In this study, the 24-to-72-h harvest interval was subdivided into 13 equidistant time points and the amino acid concentrations were measured at each time point. Our aim was to

Genetics and Molecular Research 15 (3): gmr.15038306 
provide theoretical support to guide production practices of beekeeping, as well as to elucidate the relationship between harvest time point and RJ content.

\section{MATERIAL AND METHODS}

\section{Reagents and standards}

The 17 individual amino acid standards, including aspartic acid (Asp), threonine (Thr), serine (Ser), glutamic acid (Glu), glycine (Gly), alanine (Ala), valine (Val), methionine (Met), isoleucine (Ile), leucine (Leu), tyrosine (Tyr), phenylalanine (Phe), lysine (Lys), histidine (His), arginine (Arg), proline (Pro), and cysteine (Cys), were purchased from Sigma (Shanghai, China). All the analytical grade reagents (trisodium citrate, sodium hydrate, sodium chloride, hydrochloric acid, citric acid, ethyl alcohol, phemethylol, thiodiglycol, polyoxyethylene lauryl ether, triketohydrindene hydrate, and octanoic acid) were purchased from Kelong Chemical Regent Company (Chengdu, Sichuan province, China).

\section{Samples}

The colony and RJ sample preparation followed the methods of Zheng et al. (2011). Ten colonies of genetically unrelated Apis mellifera were randomly chosen to produce fresh RJ in Chongqing, China. To ensure that the RJ production progressed smoothly and to ensure that the experimental conditions were the same, feeding with sugar was conducted throughout the experiment. Worker larvae of approximately 1 day of age were transferred into clean plastic queen cell cups. One frame containing four strips of plastic queen cups ( $\mathrm{N}=32$ per strip) was used for each colony. The frame was placed in the honey compartment of the hives. Subsequently, the queen cell frames were removed from the colonies at $24,28,32,36,40,44,48,52,56,60,64,68$, and $72 \mathrm{~h}$ after transfer. At this time, the wax covering the cups and larvae in the cells were removed. The RJ in each cup was collected within 3 min and immediately frozen at $-20^{\circ} \mathrm{C}$ and conserved at this temperature until the amino acid analysis was conducted.

\section{Moisture analysis}

The moisture analysis followed the RJ quality standard method published in 2002 by the AQSIQ (General Administration of Quality Supervision, Inspection and Quarantine of the People's Republic of China, 2002). Moisture was measured by weight loss upon drying in a vacuum drying oven.

\section{Extraction of FAAs}

$\mathrm{RJ}(0.1000 \mathrm{~g})$ was dissolved in $25 \mathrm{~mL}$ deionized water and dispersed for $15 \mathrm{~min}$ with the help of a ultrasonic cell disruptor (Xinzhi Company, Ningbo, China) until it was homogenized. To deposit the proteins, $1.5 \mathrm{~mL} \mathrm{RJ}$ solution was mixed with $8.0 \%$ sulfosalicylic acid, adding up to $6.0 \mathrm{~mL}$. The solution was centrifuged for $5 \mathrm{~min}$ at $1430 \mathrm{~g}$ and the supernatant was then filtered using a $0.45-\mu \mathrm{m}$ microporous filter, prior to injecting it into the L-8800 amino acid autoanalyzer (Hitachi Ltd, Tokyo, Japan) (González Paramás et al., 2006).

Genetics and Molecular Research 15 (3): gmr.15038306 


\section{Extraction of TAAs}

RJ $(0.1000 \mathrm{~g})$ was carefully weighted and transferred into a 20 -mL pyrex screw-cap tube. Subsequently, $10 \mathrm{~mL} 6 \mathrm{M} \mathrm{HCl}$ was added and the mix was homogenized for $1 \mathrm{~min}$ using a vortex machine (Scientific Industries Company, USA). A moderate stream of purified nitrogen was blown into the liquid to remove the air in the tube. The tightly sealed tube was then kept upright in an oven at $110^{\circ} \pm 1^{\circ} \mathrm{C}$ for $22 \mathrm{~h}$. Subsequently, the tube was removed from the oven and allowed to cool to room temperature. At this point, the acid hydrolysate was filtered through a qualitative filter paper (Jiaojie Company, Liaoning, China), neutralized to $\mathrm{pH} 7.0$ using $6 \mathrm{M} \mathrm{NaOH}$, and redissolved in deionized water to a total volume of $50 \mathrm{~mL}$. The acid hydrolysate was then filtered using a $0.45-\mu \mathrm{m}$ microporous filter (Millipore, MA, USA). Before injection into the amino acid autoanalyzer, $1 \mathrm{~mL}$ filtrate was mixed with $1 \mathrm{~mL}$ hydrochloric acid solution.

\section{Preparation of standard substance and chromatographic conditions}

Ten microliters of amino acid standards was carefully measured and transferred into volumetric flasks and filled up to $1 \mathrm{~mL}$ using deionized water. All analyses were performed on a L-8800 amino acid autoanalyzer (Hitachi Ltd., Tokyo, Japan), following the manufacturer instructions. A $4.6 \times 60 \mathrm{~mm}$ ion exchange column was used and the mobile phases comprised a buffer, triketohydrindene hydrate, and water. The flow velocity and detective wavelength of the buffer were $0.400 \mathrm{~mL} / \mathrm{min}$ and $570 \mathrm{~nm}$, respectively, whereas the flow velocity and the detective wavelength of the triketohydrindene hydrate solution were $0.350 \mathrm{~mL} / \mathrm{min}$ and $440 \mathrm{~nm}$, respectively. The temperatures of the column and reactor were set to $57^{\circ}$ and $153^{\circ} \mathrm{C}$, respectively, and the injection volume for all samples and standard solutions was $20 \mu \mathrm{L}$.

\section{Data analysis}

Microsoft Office Excel 2007 and ANOVA of the SAS 9.2 software were used to deal with data. The concentrations of FAAs were calculated using the square of the difference between the sample FAA and the corresponding standard FAA. Each sample was detected three times and the mean and SD were calculated. The calculation method of TAA concentrations were the same as FAAs. The essential amino acid (EAA) percentages were calculated based on the proportion of each particular amino acid of the total for all the amino acids.

\section{RESULTS}

\section{Moisture of RJ harvested at differential times after transfer}

The moisture of RJ harvested at the 13 different time points after transfer are shown in Figure 1. In general, the RJ moisture increased with increasing time after transfer. The highest and lowest RJ moisture contents were 50.2 and $67.2 \%$, detected at 24 and $72 \mathrm{~h}$ after transfer, respectively. An ANOVA analysis indicated that the RJ moisture harvested at 48 to $72 \mathrm{~h}$ was significantly greater than RJ harvested at 24 to $32 \mathrm{~h}$ after transfer $(\mathrm{P}<$ 0.05 ). In addition, the RJ harvested at $32 \mathrm{~h}$ was significantly greater than RJ harvested at $24 \mathrm{~h}$ after transfer $(\mathrm{P}<0.05)$.

Genetics and Molecular Research 15 (3): gmr.15038306 


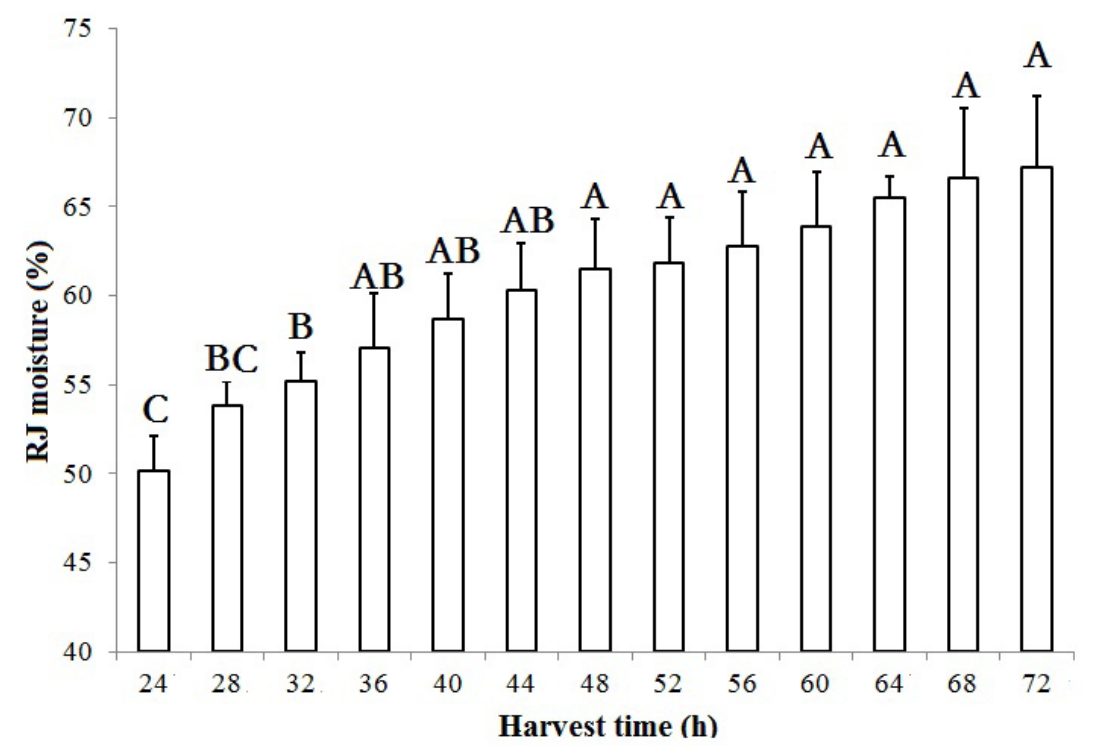

Figure 1. Moisture of royal jelly (RJ) harvested at 13 different time points between 24 and $72 \mathrm{~h}$ after transfer. The moisture was measured by weight loss upon drying in a vacuum drying oven. Different letters over each bar indicate significant differences at $\mathrm{P}<0.05$. Error bars represent $\mathrm{SD}$ of the mean of 10 samples.

\section{Chromatograms of $\mathbf{R J}$ amino acids}

Following the autoanalyzer manufacturer instructions, $20 \mu \mathrm{L}$ standard amino acid solutions were carefully injected, to obtain standard chromatograms (Figure 2). Subsequently, FAAs and TAAs were injected, to detect the sample FAA and TAA concentrations.
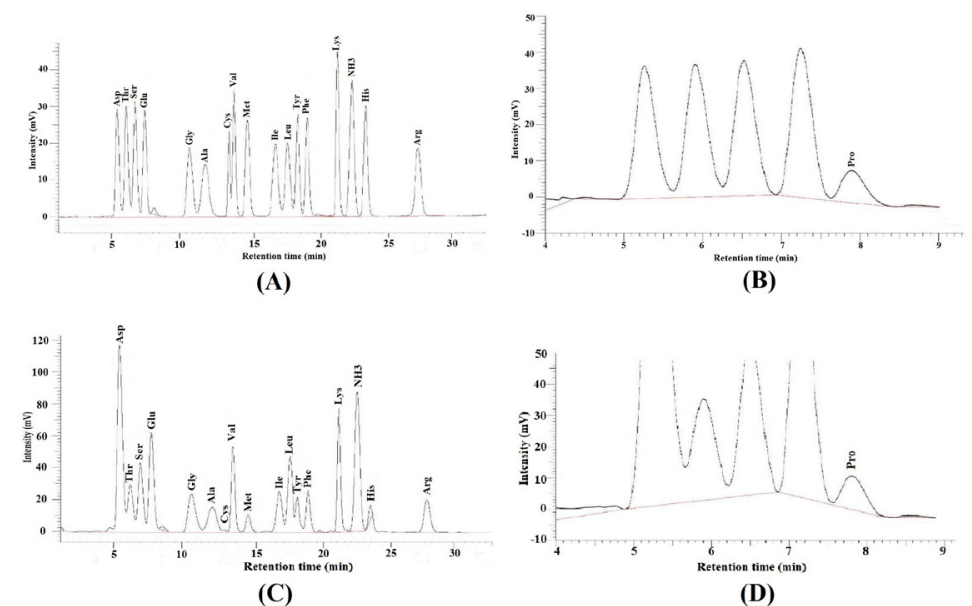

Figure 2. Chromatograms of the 18 FAAs (A and B) and TAAs (C and $\mathbf{D})$ in standard solutions. Proline FAA (B) and TAA (D) are shown separately. The detection instrument used was the L-8800 amino acid autoanalyzer (Hitachi Ltd., Tokyo, Japan) and $20 \mu \mathrm{L}$ standard solution was injected.

Genetics and Molecular Research 15 (3): gmr.15038306 


\section{FAA concentrations of $R J$ harvested at different times after transfer}

The concentrations of 17 FAAs, including Asp, Thr, Ser, Glu, Gly, Ala, Cys, Val, Met, Ile, Leu, Tyr, Phe, Lys, His, Arg, and Pro, were calculated were calculated using the square of the difference between the sample FAA and the corresponding standard FAA. Each sample was detected three times and the mean and SD was calculated. The results are presented in Table 1.

Table 1. Amino acid composition of musk deer T2R16 protein.

\begin{tabular}{l|c|c|c|c|c|c|c|c|c|c|c|c|c|c|c|c|c|c|c|c}
\hline $\begin{array}{l}\text { Amino } \\
\text { acids }\end{array}$ & Ala & Arg & Asn & Asp & Cys & Gln & Glu & Gly & His & Ile & Leu & Lys & Met & Phe & Pro & Ser & Thr & Trp & Tyr & Val \\
\hline Number & 18 & 12 & 9 & 4 & 5 & 10 & 9 & 7 & 10 & 21 & 50 & 11 & 10 & 27 & 7 & 32 & 18 & 12 & 8 & 21 \\
\hline Percentage & 6.00 & 4.00 & 3.00 & 1.30 & 1.70 & 3.30 & 3.00 & 2.30 & 3.30 & 7.00 & 16.60 & 3.70 & 3.30 & 9.00 & 2.30 & 10.60 & 6.00 & 4.00 & 2.70 & 7.00 \\
\hline
\end{tabular}

The figures represent the total number and percentage of different amino acid residues present in the T2R16 protein.

The main FAA was Pro with the concentration of $5.38 \mathrm{mg} / \mathrm{g}$, which counted for half of the total FAA detected in RJ harvested at $72 \mathrm{~h}$ after transferring. Following Pro, the most abundant FAAs were Phe (1.30 mg/g), Lys $(0.86 \mathrm{mg} / \mathrm{g})$, Glu $(0.34 \mathrm{mg} / \mathrm{g})$, and Tyr $(0.33 \mathrm{mg} / \mathrm{g})$.

The total FAA concentration in RJ increased with increasing harvest time. Overall, the lowest $(4.30 \mathrm{mg} / \mathrm{g})$ and highest $(9.48 \mathrm{mg} / \mathrm{g})$ concentrations were observed in RJ harvested at 24 and $72 \mathrm{~h}$ after transfer, respectively. The lowest and highest concentrations of Asp were 0.06 and $0.25 \mathrm{mg} / \mathrm{g}$ detected at 24 and $60 \mathrm{~h}$ after transfer, respectively. Thr was not detected at all except in RJ harvested at $72 \mathrm{~h}$ after transfer $(0.06 \mathrm{mg} / \mathrm{g})$. Ser was not detected at 32 and $52 \mathrm{~h}$, and the largest concentration was detected at $72 \mathrm{~h}$ after transfer $(0.04 \mathrm{mg} / \mathrm{g})$. Ala was not detected before $36 \mathrm{~h}$ after transfer and the highest concentration was detected at 40 and $72 \mathrm{~h}$ after transfer $(0.04$ $\mathrm{mg} / \mathrm{g}$ ). Val was not detected before $64 \mathrm{~h}$, with the exceptions of 44 and $56 \mathrm{~h}$. From $0.02 \mathrm{mg} / \mathrm{g}$ detected at the $68 \mathrm{~h}$ harvest, the concentration of Val rapidly increased to $0.10 \mathrm{mg} / \mathrm{g}$ at $72 \mathrm{~h}$. The lowest and highest concentrations of Arg were 0.03 and $0.06 \mathrm{mg} / \mathrm{g}$, harvested at 36 and $72 \mathrm{~h}$ after transfer, respectively. The RJ concentrations of Glu, Pro, Gly, Cys, Met, Ile, Leu, Tyr, Phe, Lys, and His were lowest at $24 \mathrm{~h}$ and highest at $72 \mathrm{~h}$ after transfer, respectively.

\section{TAA concentrations in RJ harvested at different times after transfer}

Following the method of Zhao (2014), the concentrations of the 17 TAAs were detected and calculated using the square of the difference between the sample TAA and the corresponding standard TAA. Each sample was detected three times and the mean and SD were calculated. The results are shown in Table 2.

Table 2. Prediction of the amino acid distribution on the transmembrane helices.

\begin{tabular}{l|l}
\hline Position on the membrane & Distribution of amino acids \\
\hline Outside & $1-9,64-82,152-182,257-260$ \\
\hline TM helix & $10-32,45-63,83-105,129-151,183-205,234-256,261-283$ \\
\hline Inside & $33-44,106-128,206-233,284-301$ \\
\hline
\end{tabular}

TM helix, transmembrane helix.

Our results showed that, at $72 \mathrm{~h}$ after transfer, the most abundant TAA was Asp, with a concentration of $22.27 \mathrm{mg} / \mathrm{g}$, followed by Glu $(16.94 \mathrm{mg} / \mathrm{g})$, Leu $(10.65 \mathrm{mg} / \mathrm{g})$, Lys

Genetics and Molecular Research 15 (3): gmr.15038306 
$(9.10 \mathrm{mg} / \mathrm{g})$, and $\mathrm{Val}(8.13 \mathrm{mg} / \mathrm{g})$. The concentration variation trend of the TAAs was more consistent compared to the FAAs. As is shown in Table 2, the concentration of all the TAAs combined was highest at $24 \mathrm{~h}(197.96 \mathrm{mg} / \mathrm{g})$. It then rapidly decreased to $149.53 \mathrm{mg} / \mathrm{g}$ at 40 h. Subsequently, an increase to $169.62 \mathrm{mg} / \mathrm{g}$ was observed at $52 \mathrm{~h}$, followed by a consistent decrease until $72 \mathrm{~h}(121.32 \mathrm{mg} / \mathrm{g})$. Consistent with the overall pattern, Asp, Thr, and Ser displayed the decrease-increase-decrease pattern over time, with the intermediate increase occurring between 40 and $52 \mathrm{~h}$. In the other TAAs some variation in the intermediate patterns were observed, but without exception, all TAAs consistently showed the overall high and low occurring at 24 and $72 \mathrm{~h}$, respectively.

\section{Analysis of EAAs in RJ harvested at different times after transfer}

The contents and proportions of EAAs play a pivotal role in estimating the nutrition value of food. These days, the amino acid contents recommend by WHO/FAO is widely used to measure the EAAs in food. The EAA concentrations in RJ harvested at different times are presented in Table 3. Our results indicated that, with the exception of Met and Phe, the proportions of Val, Ile, Leu, Thr, and Lys were higher than the standard values recommend by $\mathrm{WHO} / \mathrm{FAO}$ at all time points. The highest and lowest proportions of total EAAs were 40.10 and $35.33 \%$, occurring at 36 and $64 \mathrm{~h}$, respectively.

Table 3. Identity of T2R16 amino acid sequences between forest musk deer and other species.

\begin{tabular}{l|l|l|c}
\hline Species & GenBank ID & Definition & Identity (\%) \\
\hline Bos taurus & NM_001046628.1 & Taste receptor, type 2, member 16 (TAS2R16) & 94.48 \\
\hline Ovis aries & XM_004008021.1 & Predicted: taste receptor type 2 member 16-like (LOC101105240) & 94.37 \\
\hline Tursiops truncatus & KJ524798.1 & Taste receptor type 2 member 16 (Tas2r16) pseudogene, complete sequence & 85.6 \\
\hline Sus scrofa & XM_003134749.1 & Predicted: taste receptor type 2 member 16-like (LOC100513769) & 81.95 \\
\hline Camelus bactrianus & XM_010947595.1 & Predicted: taste receptor type 2 member 16 (LOC105063129) & 79.58 \\
\hline Equus przewalskii & XM_008514411.1 & Predicted: taste receptor type 2 member 16 (LOC103547299) & 79.58 \\
\hline Camelus dromedarius & XM_010975603.1 & Predicted: taste receptor type 2 member 16 (LOC105085339) & 79.47 \\
\hline Pteropus vampyrus & XM_011357170.1 & Predicted: taste receptor type 2 member 16 (LOC105290162) & 79.14 \\
\hline Myotis brandtii & XM_005878870.1 & Predicted: taste receptor type 2 member 16-like (LOC102256244) & 77.15 \\
\hline Pan troglodytes & NM_001009160.1 & Taste receptor, type 2, member 16 (TAS2R16) & 76.03 \\
\hline Homo sapiens & NM_016945.2 & Taste receptor, type 2, member 16 (TAS2R16) & 75.28 \\
\hline Macaca mulatta & NM_001080759.1 & Taste receptor, type 2, member 16 (TAS2R16) & 75.23 \\
\hline Callithrix jacchus & XM_002752064.2 & Predicted: taste receptor, type 2, member 16 (TAS2R16) & 72.96 \\
\hline
\end{tabular}

\section{DISCUSSION}

$\mathrm{RJ}$ is a complex compound containing $60-70 \%$ moisture; however, few studies have studied investigated the moisture content in RJ harvested before $72 \mathrm{~h}$ after transfer. Zheng et al. (2011) showed that the moisture contents of RJ harvested at 24, 48, and $72 \mathrm{~h}$, were $53.3,62.8$, and $64.3 \%$, respectively. In this study, a total of 13 time points were investigated from 24 to $72 \mathrm{~h}$. Our results indicated that the lowest and highest moisture contents were 50.2 and $67.2 \%$ at 24 and $72 \mathrm{~h}$ after transfer, respectively. A constant increase in moisture content was observed in RJ between these time points (Figure 1), which was consistent with the observations of Zheng et al. (2011).

In the present study, the total FAA concentration in RJ was found to increase consistently with increasing harvest time. This indicates that the FAA consumption of young larvae decreased over time. The total FAA concentration in RJ was $9.48 \mathrm{mg} / \mathrm{g}$ at $72 \mathrm{~h}$. This finding was similar to that of Wu et al. (2009) $(9.21 \mathrm{mg} / \mathrm{g})$. The slightly higher value observed

Genetics and Molecular Research 15 (3): gmr.15038306 
in the present study may be due to differences in location and food source. The most abundant FAA was Pro, with $5.38 \mathrm{mg} / \mathrm{g}$ RJ harvested at $72 \mathrm{~h}$ after transfer, which was consistent with the results in previous studies (Takenaka, 1987; Boselli et al., 2003; Wu et al., 2009). Given that RJ is the only food for the queen and young bee larvae, Pro may play an important role in bee growth.

Amino acids are the basic component of proteins, and changes in the TAA concentration are therefore believed to reflect changes in RJ protein contents. Zheng et al. (2011) reported that the crude protein contents in RJ harvested at 24, 48, and $72 \mathrm{~h}$ after grafting were 19.6, 16.2, and $15.0 \%$, respectively. In agreement with these changes in RJ protein, our data indicated that the TAA concentrations in RJ harvested at the same time points were 197.96, 157.06, and $121.32 \mathrm{mg} / \mathrm{g}$, respectively. However, the change in concentration observed was not a simple decrease. Following a steady decrease from 24 to $40 \mathrm{~h}(149.53 \mathrm{mg} / \mathrm{g})$, an increase was observed from 40 to $52 \mathrm{~h}(169.62 \mathrm{mg} / \mathrm{g})$, followed by a decrease to $72 \mathrm{~h}$. The rapid decrease in TAA concentration in RJ harvested before $40 \mathrm{~h}$ after grafting may be caused by a dilution effect driven by the rapid increase in moisture. Together with secretion of TAAs from worker honey bees, a reduction in the moisture increase may have resulted in the observed increase in TAA concentration to $169.62 \mathrm{mg} / \mathrm{g}$ at $52 \mathrm{~h}$. The rapid decrease in TAA concentration observed after $52 \mathrm{~h}$ may have been caused by a dilution effect due to increased moisture content combined with higher larval consumption as the larvae grew bigger and bigger. The five most abundant amino acids in RJ harvested at $72 \mathrm{~h}$ included Asp, Glu, Leu, Lys, and Val. These results are in agreement with the findings of Zheng et al. (2011) and showed only minor differences compared to those of Zhao (2014) who observed that the five most abundant amino acids, including Asp, Glu, Pro, Leu and Lys, in RJ which was purchased in the market. The minor discrepancies found may be due to differences of RJ samples.

The contents and proportions of EAAs play a pivotal role in estimating the nutrition value of food. Previous studies have detected eight EAAs in RJ (Wu et al., 2009). In contrast, only seven EAAs were detected in the present study. Because the samples in this study were treated with acid hydrolysis, all Trp were destroyed. A more appropriate method is needed for a complete amino acid investigation of RJ. Our data indicated that the proportions of all EAAs except Met and Phe were higher than the standard values recommended by WHO/FAO, which was in agreement with the findings by Zhao (2014).

In conclusion, or results indicated that the moisture of RJ increased consistently from 24 to $72 \mathrm{~h}$ after transfer. The total FAA concentration in RJ increased with increasing harvest time, from 4.30 to $9.48 \mathrm{mg} / \mathrm{g}$, at 24 and $72 \mathrm{~h}$, respectively. The most abundant FAAs were Pro, Phe, Lys, Glu, and Tyr. The variation in concentration observed in the TAAs was more consistent than that observed in the FAAs. The five most abundant TAAs were Asp, Glu, Leu, Lys, and Val. With the exception of Met and Phe, all the EAA proportions were higher than the standard value recommended by WHO/FAO. To our knowledge, this is the first study on the changes in FAA and TAA concentration prior to $72 \mathrm{~h}$ after transfer. This provides theoretical support that may guide the production practices of beekeeping, as well as an in-depth study of the relationships between harvest time point and RJ contents.

\section{Conflicts of interest}

The authors declare no conflict of interest.

Genetics and Molecular Research 15 (3): gmr.15038306 


\section{ACKNOWLEDGMENTS}

We thank He Sao-yu from Yunnan Agricultural University for his expert technical assistance. Research supported by the fundamental research funds for the Chongqing Science \& Technology Commission, China (\#2014cstc-jbky-01303 and \#2014cstc-jbky-01302), the Science \& Technology Innovation Program of Nanchuan District, Chongqing, China (\#CX201216), and the Chinese Medicinal Science and Technology Project of Chongqing Sanitary Bureau (\#2012-2-156).

\section{REFERENCES}

Bíliková K, Wu GS and Šimúth J (2001). Isolation of a peptide fraction from honeybee royal jelly as a potential antifoulbrood factor. Apidologie 32: 275-283. http://dx.doi.org/10.1051/apido:2001129

Boselli E, Caboni MF, Sabatini AG, Marcazzan GL, et al. (2003). Determination and changes of free amino acids in royal jelly during storage. Apidologie 34: 129-137. http://dx.doi.org/10.1051/apido:2003011

Chen C and Chen SY (1995). Changes in protein components and storage stability of royal jelly under various conditions. Food Chem. 54: 195-200. http://dx.doi.org/10.1016/0308-8146(95)00031-D

Chen SL, Su SK and Lin XZ (2002). An introduction to high-yielding royal jelly production methods in China. Bee World 83: 69-77. http://dx.doi.org/10.1080/0005772X.2002.11099543

Crane E (1990). Bees and beekeeping: science, practice and world resources. Heinemann Newnes, Oxford.

General Administration of Quality Supervision, Inspection and Quarantine of the People's Republic of China (2002). Royal Jelly, GB/T 9697-2002. AQSIQ, Beijing.

González Paramás AM, Gómez Bárez JA, Cordón Marcos C, García-Villanova RJ, et al. (2006). HPLC-fluorimetric method for analysis of amino acids in products of the hive (honey and bee-pollen). Food Chem. 95: 148-156. http:// dx.doi.org/10.1016/j.foodchem.2005.02.008

Guo H, Kouzuma Y and Yonekura M (2009). Structures and properties of antioxidative peptides derived from royal jelly protein. Food Chem. 113: 238-245. http://dx.doi.org/10.1016/j.foodchem.2008.06.081

Han F, Wallberg A and Webster MT (2012). From where did the Western honeybee (Apis mellifera) originate? Ecol. Evol. 2: 1949-1957. http://dx.doi.org/10.1002/ece3.312

Howe SR, Dimick PS and Benton AW (1985). Composition of freshly harvested and commercial royal jelly. J. Apic. Res. 24: 52-61.

Karaca T, Şimşek N, Uslu S, Kalkan Y, et al. (2012). The effect of royal jelly on CD3(+), CD5(+), CD45(+) T-cell and CD68(+) cell distribution in the colon of rats with acetic acid-induced colitis. Allergol. Immunopathol. 40: 357-361. http://dx.doi.org/10.1016/j.aller.2011.09.004

Kim J, Kim Y, Yun H, Park H, et al. (2010). Royal jelly enhances migration of human dermal fibroblasts and alters the levels of cholesterol and sphinganine in an in vitro wound healing model. Nutr. Res. Pract. 4: 362-368. http://dx.doi. org/10.4162/nrp.2010.4.5.362

Knecht D and Kaatz HH (1990). Patterns of larval food production by hypopharyngeal glands in adult worker honey bees. Apidologie 21: 457-468. http://dx.doi.org/10.1051/apido:19900507

Kucharski R, Maleszka J, Foret S and Maleszka R (2008). Nutritional control of reproductive status in honeybees via DNA methylation. Science 319: 1827-1830.http://dx.doi.org/10.1126/science.1153069

Lercker G, Capella P, Conte LS and Ruini F (1981). Components of royal jelly: I. Identification of the organic acids. Lipids 16: 912-919. http://dx.doi.org/10.1007/BF02534997

Matloubi H, Aflaki F and Hadjiezadegan M (2004). Effect of g-irradiation on amino acids concentration of baby food proteins. J. Food Compos. Anal. 17: 133-139. http://dx.doi.org/10.1016/j.jfca.2003.09.005

Mihajlovic D, Vucevic D, Chinou I and Colic M (2014). Royal jelly fatty acids modulate proliferation and cytokine production by human peripheral blood mononuclear cells. Eur. Food Res. Technol. 238: 881-887. http://dx.doi. org/10.1007/s00217-014-2154-7

Nation JL and Robinson FA (1971). Concentration of some major and trace elements in honeybees, royal jelly and pollens, determined by atomic absorption spectrophotometry. J. Apic. Res. 10: 35-43.

Scarselli R, Donadio E, Giuffrida MG, Fortunato D, et al. (2005). Towards royal jelly proteome. Proteomics 5: 769-776. http://dx.doi.org/10.1002/pmic.200401149

Shen JK (1991). The effect of harvest period on the yield of royal jelly. Apic. China 6: 2-4.

Genetics and Molecular Research 15 (3): gmr.15038306 
Takenaka T (1987). Nitrogen components and carboxylic acids of royal jelly. In: Chemistry and biology of social insects (Eder J and Rembold H, eds.). Verlag J. Pepemy, Munich, 162-163.

Tamura T, Fujii A and Kuboyama N (1987). Antitumor effects of royal jelly (RJ). Nippon Yakurigaku Zasshi 89: 73-80. http://dx.doi.org/10.1254/fpj.89.73

Tokunaga KH, Yoshida C, Suzuki KM, Maruyama H, et al. (2004). Antihypertensive effect of peptides from royal jelly in spontaneously hypertensive rats. Biol. Pharm. Bull. 27: 189-192. http://dx.doi.org/10.1248/bpb.27.189

Townsend GF and Lucas CC (1940). The chemical nature of royal jelly. Biochem. J. 34: 1155-1162. http://dx.doi. org/10.1042/bj0341155

Townsend GF, Morgan JF and Hazlett B (1959). Activity of 10-hydroxydecenoic acid from royal jelly against experimental leukaemia and ascitic tumours. Nature 183: 1270-1271. http://dx.doi.org/10.1038/1831270a0

Wu LM, Zhou JH, Xue XF, Li Y, et al. (2009). Fast determination of 26 amino acids and their content changes in royal jelly during storage using ultra-performance liquid chromatography. J. Food Compos. Anal. 22: 242-249. http:// dx.doi.org/10.1016/j.jfca.2008.10.022

Zhao L (2014). Amino acids composition and nutritional functions analysis of royal jelly. Food Res. Dev. 35: 94-96.

Zheng HQ, Hu FL and Dietemann V (2011). Changes in composition of royal jelly harvested at different times: consequences for quality standards. Apidologie 42: 39-47. http://dx.doi.org/10.1051/apido/2010033

Genetics and Molecular Research 15 (3): gmr.15038306 